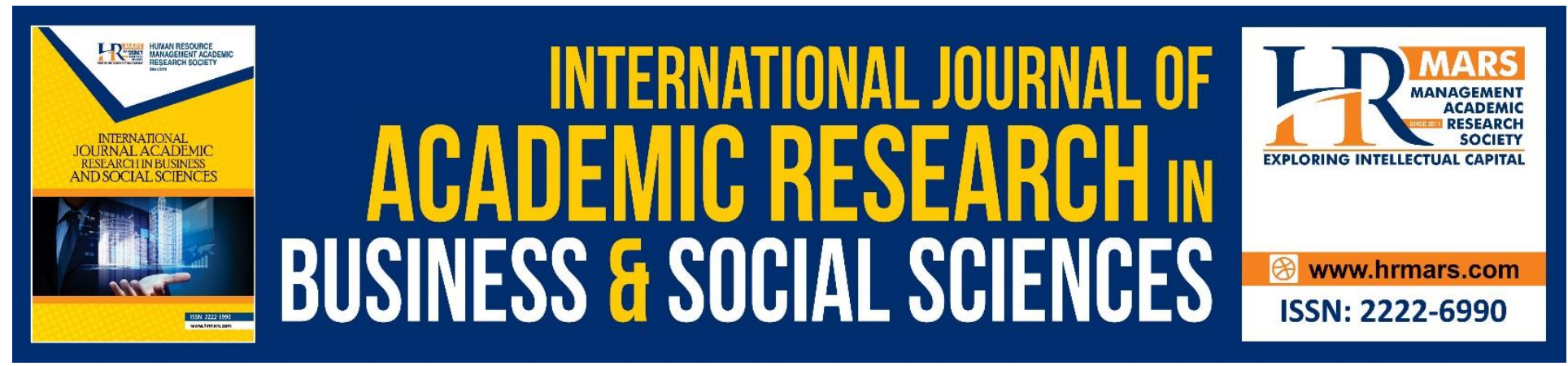

\title{
Infopreneur: Education for Economic Growth
}

\section{Saiful Farik Mat Yatin, Hasnah Shuhaimi, Aszunarni Ayob}

To Link this Article: http://dx.doi.org/10.6007/IJARBSS/v8-i12/5250

DOI: $10.6007 /$ IJARBSS/v8-i12/5250

Received: 17 Nov 2018, Revised: 19 Dec 2018, Accepted: 30 Dec 2018

Published Online: 16 Jan 2019

In-Text Citation: (Yatin, Shuhaimi, \& Ayob, 2018)

To Cite this Article: Yatin, S. F. M., Shuhaimi, H., \& Ayob, A. (2018). Infopreneur: Education for Economic Growth. International Journal of Academic Research in Business and Social Sciences, 8(12), 1460-1476.

Copyright: (C) 2018 The Author(s)

Published by Human Resource Management Academic Research Society (www.hrmars.com)

This article is published under the Creative Commons Attribution (CC BY 4.0) license. Anyone may reproduce, distribute, translate and create derivative works of this article (for both commercial and non-commercial purposes), subject to full attribution to the original publication and authors. The full terms of this license may be seen at: http://creativecommons.org/licences/by/4.0/legalcode

Vol. 8, No. 12, 2018, Pg. 1460 - 1476

Full Terms \& Conditions of access and use can be found at http://hrmars.com/index.php/pages/detail/publication-ethics 


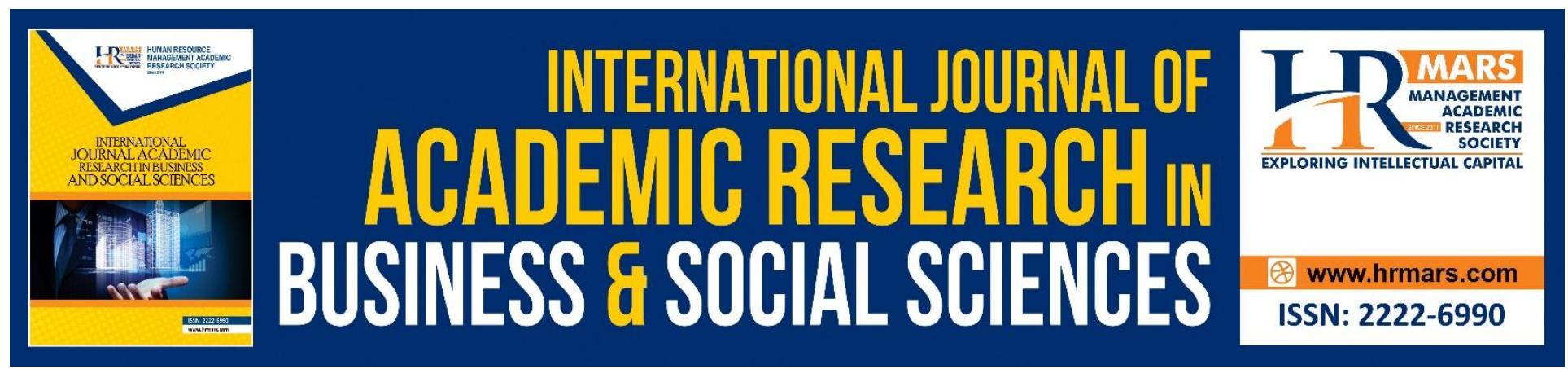

\title{
Infopreneur: Education for Economic Growth
}

\author{
1,2Saiful Farik Mat Yatin, ${ }^{1}$ Hasnah Shuhaimi, ${ }^{3}$ Aszunarni Ayob \\ ${ }^{1}$ Faculty of Information Management, Universiti Teknologi MARA (UiTM) Selangor, Malaysia \\ ${ }^{2}$ Members of Advanced Analytics Engineering Center (AAEC), Universiti Teknologi MARA (UiTM) \\ Shah Alam, Malaysia \\ ${ }^{3}$ Faculty of Education, Universiti Kebangsaan Malaysia \\ Email: farik@salam.uitm.edu.my
}

\begin{abstract}
Information management is a cornerstone of any organization, along with operations management, customer management and resource management. Managing and recording what the organization creates, use and maintain the information and preserve it in secure archive is paramount to the organization success. Failure to manage this information will expose the business to potential risks and liabilities. These issues will be the challenges for university graduates to become versatile and competent information professional. This paper aimed to determine the employability trend from the students of the Faculty of Information Management (FIM) Universiti Teknologi MARA (UiTM) and if these graduates and their academic-acquired skills and competencies are related to their field of study in their present occupation. This paper also investigates the effectiveness of entrepreneurship education that has been embedded in the university curriculum where UiTM has been awarded as the Entrepreneurial University for three consecutive years (2012-2015) by the Minister of Education, Malaysia. Three years' data were analyzed from Graduate Tracer Study questionnaire (2013-2015). The data focus on graduates from the Faculty of Information Management (FIM) as they are the potential respondent in becoming inforpreneur. It was analyzed descriptively and showed through tabulated and diagrammatized form to discuss the findings. The results proved that FIM produces marketable and appropriately trained graduates but the majority of them not working in course-related jobs. FIM graduates are still low in initiating their own business, failure in exploring the potential growth in information management industry. Therefore, in depth understanding about the entrepreneurship education, potential business of information management (IM) industry such as Commercial Record Centre (CRC) and Enterprise Content Management (ECM) etc. need to be address so that FIM graduates aware of the potential in this industry and can aggressively initiating their own business in future thus reducing the employability issues that faced by the university.
\end{abstract}


INTERNATIONAL JOURNAL OF ACADEMIC RESEARCH IN BUSINESS AND SOCIAL SCIENCES Vol. 8, No. 12, Dec, 2018, E-ISSN: 2222-6990 ㄷ 2018 HRMARS

Keyword: information entrepreneur, infopreneur, employability, commercial record center, information management industry

\section{INTRODUCTION}

Information management (IM) is a cornerstone of any organization, along with operations management, customer management and resource management. Managing and recording what the organization creates, use and maintain the information and preserve it in secure archive is paramount to the organization success. Failure to manage this information will expose the business to potential risks and liabilities. These issues will be the challenges for university graduates to become versatile and competent information professional. Infopreneurial behaviour amongst University graduates has the potential to guarantee employment and bridge the gap between job-security and the perceived insecurity of an own information business (David and Dube 2013, 262).

The importance of information nowadays is experiencing significant growth from time to time. The power of information sometimes had overwritten the power of money. The unstoppable creation and sharing of information in everyday life led to an information explosion. We are surrounded with lots of information and to some extent, we are drowning in it. Information overload, information explosion, infobesity, infoxication, information glut, data smog, internet of things and currently big data were among the phenomena that express the rapid increase amount of information. This requires experts who can find, sort and process it. As a result, the emergence terms such as information broker, information consultant as well as information entrepreneur (infopreneur) has stolen the limelight.

Before the explosive popularity of the Internet at the turn of the millennium, such an occupation already exist involving librarian, records manager, and Information Technology (IT) manager. These legacy infopreneurs sold their information in other mediums such as audio tapes, audio CDs, CD-ROMs, videos, talk shows and conferences. Librarian manages the monograph collection before the digital edge. Records manager on the other hand, manage primary source records or unpublished materials while IT manager manages information that resides in a computer/database. Due to online information grows rapidly in unimaginable numbers, librarian and record manager, does not only deals with printed materials or information but also in digital form. Unlimited information in digital forms is easily accessed by users as long as there is internet access. The classification of infopreneur also has created a new style of business on the Internet, which allows anybody (not only from the IM field) with a computer and an Internet connection to start businesses by publishing information that may appeal to a specific market.

To certain extend, the borderline between information broker, information consultant, and information entrepreneur is almost unseen. The job scope of the person involved in these fields, sometimes overlapped between one another. They advise, search and provide all relevant and required information as demanded by customers. But the level, urgency, amount of the information might help to draw the line. 


\section{DEFINITIONS OF INFORMATION ENTREPRENEUR}

Information has more value than physical inventory. Information is the future (Khosrowjerdi, 2014, 52). Basically, information is a physical commodity that can be produced, purchased, replicated, distributed, manipulated, passed along, controlled, traded and sold (Ikoja-Odongo $2006,147)$ also as a resource (Toit, 2000, 86). Toit also defined entrepreneur as someone who mobilizes production factors to produce product or services. Combining these two words (information entrepreneur) or infopreneur will create a person who is willing to take all the risks with information product and services.

Limited information searching skills, money constraints, time constraint as well as limited access to online information services have empowered the roles of information entrepreneurs. They are capable of assisting, search, evaluate, consult and provide the required information to its customers. Loads of information from various sources might cause confusion among users in searching for the right information. Based on these facts, in developed countries, information broker, information consultant and information entrepreneurs have created lots of job opportunities.

Weitzen registered a trademark for "infopreneur", indicating its first use in commerce was as of January 31, 1984 (Lahm and Stowe 2011, 107). Usually, the term is referred to any person whose primary business is gathering and selling electronic information. By various definitions, infopreneur is information professional:

- who is skilled in a number of areas, for example, skills as mediators between "flood of information" and the information needed by their clients client (Christozov et.al. 2008, 89)

- who sells his or her research expertise to provide the information to his/her core audience wants to buy (Khosrowjerdi 2014, 50)

- who want to capitalize on the sea of opportunities available on the internet to define their niche markets. (Chew 2010).

- who identifies opportunities for creating enterprising information-based businesses (David \& Dube 2014, 19)

- who is known as information intermediaries (Ramugondo, 2010, 2).

Effective utilization of (ICT's) has unarguably changed the way people interact. These have resulted in the creation of new knowledge, products, jobs and services and infopreneurship is one of such new fields that have become an innovation into the mainstream information practice with the potential to limit the unemployment rate of graduates, enhance per-capita income and advance economic growth.

The development of information entrepreneurs bridges the gap between the consumers and the information. Information entrepreneurs are able to sift and repackage information that is or may be more relevant to consumers, vis-à-vis consumers trying to achieve such on their own. Market changes are rapid; consumers are unable to cope with the ever-changing economy, information availability and accessibility. The existence of information entrepreneurs reduces strain on the 
INTERNATIONAL JOURNAL OF ACADEMIC RESEARCH IN BUSINESS AND SOCIAL SCIENCES Vol. 8, No. 12, Dec, 2018, E-ISSN: 2222-6990 ㄷ 2018 HRMARS

consumers while aiding the consumers in achieving and realising their information needs. (Dick, 2002).

\section{HISTORY OF RIDA, MARA, ITM and UITM}

Universiti Teknologi MARA (UiTM) (English: MARA University of Technology)

is a public university in Malaysia. Established in 1956 as RIDA (Rural and Industrial Development Authority) Training Centre (Malay: Dewan Latehan RIDA), it opened its door to some 50 students with a focus to help the rural Malays. The training center later became known as MARA College (Malay: Maktab MARA) in 1965. The name change meant that the college no longer operated under RIDA and instead became the most important unit of the MARA Training Division.

In 1967, the college was upgraded to MARA Institute of Technology (Malay: Institut Teknologi MARA, ITM). Its establishment came as a response to a need in Malaysia for trained professionals, especially among bumiputeras ${ }^{1}$. Acknowledging the fact that education holds the key to positive social engineering processes, ITM has made education easily accessible primarily to the bumiputera Malays and indigenous bumiputera of the Malay Peninsula and those from the East Malaysia.

The third phase (1996-1999) came about as a result of an amendment to the ITM Act 1976 which granted the institution all the powers of a university and on par with all the universities in the country, despite retaining its name. In August 1999, the Prime Minister $\mathrm{Dr}$ Mahathir Mohamad announced the change in name of ITM to MARA University of Technology (Malay: Universiti Teknologi MARA, UITM). As UITM moves forward, it remains focused on academic excellence, innovation, socio-economic goals, worldwide accreditation, globalization and new technologies in order to contribute to industry and national development.

UiTM has grown into the largest higher education institution in Malaysia by its physical infrastructure, staffs (academic and non-academic) and student's enrollment. The university comprises one main campus, 13 autonomous state campuses and 21 satellite campuses. With 17,000 of academics and non-academics staff, UiTM offered some 500 programs ranging from foundation to postgraduate level. It is home to some 168,000 students: bumiputeras and international students, in full-time and part-time mode. The teaching is fully conducted in English (UiTM 2016). As of November 2016, UiTM has produced a record of 687,176 graduates (Nazrin 2016).

\section{INFORMATION MANAGEMENT AS A FIELD IN EDUCATION}

To maintain and sustain the economy growth of a nation, the governments all over the world have invested in education from different disciplines that is needed for the market workforce. Since 1968 - Faculty of Information Management FIM (2016) is the pioneer in providing

\footnotetext{
${ }^{1}$ Bumiputera or Bumiputra (Jawi: بوميقوترا) is a Malaysian term to describe the Malay race and other indigenous peoples of Southeast Asia, and used particularly in Malaysia. The term comes from the Sanskrit word bhumiputra ( $\square \square \square \square \square \square \square \square \square$ ), which can be translated literally as "son of the land" or "son of the soil" (bhumi= earth or land, putra=son). https://en.wikipedia.org/wiki/Bumiputera_(Malaysia)
} 
professional education to fulfill the manpower need of the country in three very important fields, namely: Information Management, Library Management, and Records Management. With the tagline Preserving the Past, Valuing the Present, Enriching the Future, FIM graduates has become the main driving force for the development of a knowledge-based society, transforming Malaysia into a developed nation, ensuring that the country's rich reservoirs of knowledge are systematically organized, maintained and enhanced for optimum value. The programs consist of blended components from four main areas: Information Technologies, Professional and Technical Aspects of Information and Records Management, Public Relations, and Users' Needs and Services. With 12 programs offered by the faculty, from Diploma to PhD, FIM has already produce more than 20,000 graduates (UiTM 2016)

The strengths of the faculty are evidenced in the achievements of its graduates and alumni who have been playing a leading role in the administration of various libraries, archives, resource center and information technology department throughout Malaysia. Altogether they form the pillars of strength for national development rooted in good principles and best practices in IM and various sectors of society. The faculty takes pride in being the pioneer and sole provider of quality education in these critical fields needed for propelling the country towards the Knowledge-based society.

\section{UITM AS ENTREPRENEUR UNIVERSITY}

Government and the higher education sector have been working together over a number of years to increase the impact of the higher education knowledge base on business and society. Higher Education Institution (HEI) appears to be one of the driving factors which can help to translate the knowledge output of the university into business innovation or entrepreneurship by embedding and fostering enterprising culture into the system and policy. Entrepreneurial university describes the university-level activities towards commercialization of its research products. Such activities can be visualized from both the functions and cohesion of a system in ensuring the internal and external elements that can inhibit or enhance entrepreneurial activity. The activities including any published research pertaining to entrepreneurial activities in which a university could be involved, including, but not limited to: patenting, licensing, creating new firms, facilitating technology transfer through incubators and science parks, and facilitating regional economic development (Rothaermel et.al. 2007, 692). Although still a fledgling compared to other more established universities in the country, UiTM has earned a reputation as being one of Malaysia's innovative and entrepreneurial universities, as it has formed linkages with numerous and diverse industrial sectors. Hence, its relationships with the industries have enriched its research and innovation as well as its entrepreneurial culture and have been acknowledged as an Entrepreneur University for 3 consecutive years $(2012,2013,2015)$ from the Ministry of Higher Education of Malaysia.

Sahol (2014) shared that among the strategies implemented for providing conducive ecosystem for entrepreneurship agenda in UiTM was: 
1. Establishing Malaysian Academy of SME and Entrepreneurship Development (MASMED);

2. Setting up of entrepreneurship centers at branch campuses;

3. Developing academic programs;

4. Organizing acculturation programs;

5. Creating programs for nascent entrepreneurs;

6. Recognizing staff involvement in innovation and entrepreneurship activities;

7. Encouraging innovations;

8. Developing new pedagogical initiatives to encourage higher degree of learner autonomy and produce more entrepreneurial graduates;

9. Introducing new initiatives and procedures on cost reduction and income generation to support new activities and lessen dependency on public funds;

10. Promoting social entrepreneurship and encouraging spirit of volunteerism among staff and students;

11. Introducing a flagship social programmed for uplifting the social mobility of the most underprivileged segment of the society (MDAB);

12. Establishing RIBU to manage intellectual property and facilitate commercialization of research findings;

13. Building the UiTM-MTDC technopreneur incubation center to spearhead commercialization efforts;

14. Establishing an innovation academy to nurture creativity and innovative thinking among postgraduate students.

\section{ISSUES, CHALLENGES AND FUTURE SCENARIO IN BUMIPUTERA ENTREPRENEURSHIP}

In order to formulate and implement an effective strategy for entrepreneurship development, the University would have to tackle issues of competing institutional agendas, resource allocation and staff motivation and reward (Kroll 2008, 300) in carrying out its activities. Such activities are directed towards achieving a learning culture, which will result in greater numbers of students equipped and enthused to identify, create, initiate and successfully manage personal, business, work and community issues (NCGE 2016). Universities have the responsibility of teaching the people who will work, lead and innovate in future. Entrepreneurship education should therefore, benefit not only students, but add greatly to wealth creation and economic growth.

UiTM (2014) have highlighted some of the issues, challenges and future scenarios in a workshop that focus on the issues of Bumiputera Economic Equity that is less than $30 \%$ as it continues to maintain the current equity at $23 \%$, a contentious figure among economists. Bumiputeras make up $67 \%$ of the population of the country and if GLC companies' equity was monetized, the entire equity held by Bumiputera's should exceed the $30 \%$ threshold. Other issue been discussed was the over populated of programs for soft skills development with varying degree of focus and emphasis i.e. Student Centre Learning, Outcome Based-Education (OBE); shared mindset misalignment between the University's aspiration and the students' motivation; support for financial, manpower, physical, practical and other implications on realizing the entrepreneurial 
agenda; should all diploma and degree students attend motivation courses to instill in them the belief that it is attitude not aptitude that determines altitude of becoming the entrepreneur.

The challenges been discussed was an open economy that makes the country susceptible to external impact thereby undermining effort to strengthen Bumiputera survival; limited job opportunity in public sector due to downsizing trend; weak implementation due to changing targets and priority, i.e. Kemahiran Insaniah (Soft skills); should students be given more exposure to industries and other institutions?; are UiTM getting the needed support from the external stakeholders, i.e. Multi-National Corporations (MNC) and industries and should UiTM students impart entrepreneurial skills to start own businesses and employ others rather than flood the job market? Sahol (2014) also presented the challenges faced by UiTM by focusing on the size of UiTM and the mix of courses offered, diverse quality and background of students, measurement and evaluation, teaching and learning strategies, maintaining full support and services and provision for coordinated university-wide entrepreneurship education policy.

The future scenario was to inculcate and nurture the spirit of "value-innovation" as a way of living - not just fad and fancies. Global graduates in the context of producing entrepreneur, intrapreneur, sociopreneuer, (infopreneur) etc in support of government vision of high income by 2020 through a more inclusive Bumiputera participation in economy.

\section{INFOPRENEUR CURRICULUM SUITABILITY}

The curriculum of infopreneurship was designed to enhance infopreneurial behavior among graduates in higher education institutions as it has the potential to guarantee employment by sharpening their entrepreneurship skills and end up with managing their own information-based business. Infopreneur is essential to be included in the curriculum of Information Science as its setting a balance between teaching entrepreneurial skills and managerial skills. Educators, trainers and developers should establish what needs to be done in terms of course provision, competency assessment and learning support to produce information entrepreneurs. The introduction of infopreneurship courses at higher institutions presents benefits and should be adapted and practically orientated in ways to meet the unique needs of the University graduates.

Although researchers argue that only a few students might have moderate to strong entrepreneurial skills and abilities, graduates who attend infopreneurship courses will certainly have a fuller understanding of the entrepreneurial phenomenon, and possibly become and entrepreneurs in the future (Toit, 2000, 90). Some authors stated the importance of this entrepreneurship education as:

- It may help unemployed information professionals to find new career paths (Christozov et al., 2008, 93).

- Can shape up competitive information business and guaranteeing career occupations for graduates in information science (Coulson-Thomas 2011, 156). 
INTERNATIONAL JOURNAL OF ACADEMIC RESEARCH IN BUSINESS AND SOCIAL SCIENCES Vol. 8, No. 12, Dec, 2018, E-ISSN: 2222-6990 ㄷ 2018 HRMARS

- Have the potential to create outstanding information content businesses that relies on infopreneurship education to start viable infopreneurship businesses (David \& Dube 2013, 1).

The curriculum content and methods of training in the institutions that offers information related courses need to be refocused and upgraded in order to meet with the demands of the times. By doing so, infopreneurship will certainly go a long way to help make people's lives better by way of improving competitiveness on digital services, boosting economic growth, creating jobs and enhancing other countless new products and services of the digital era (El-Kalash \& Aniki 2016, 247).

UiTM core subject for undergraduates that offers information entrepreneurship courses to degree level students in FIM was Entrepreneurship (ENT300) and Principles of Entrepreneurship (ENT530). The syllabus and course outline is interrelated to the selling, marketing and promotion of information products and services categorized.

The rationale behind developing this infopreneur curriculum is that University graduates should look at the world of the information entrepreneur as optional opportunities for new or future career, as well as offer numerous possibilities for people with entrepreneurial skills in line with the rapid changes in information technology. To this end, infopreneur courses are designed with the aim of supplying undergraduates with knowledge and understanding that could enable them to pursue infopreneurship as a career choice.

\section{OBJECTIVES OF THE STUDY}

The main purpose of this paper was for the researchers to investigate the employment status of the graduates and determine what percentage of the graduates had acquired the first job after they graduated. The concepts that the researchers had to indulge in were to look on the graduates' important profiles and to assess whether or not these profiles had satisfied their expectations so that whatever results they could account for would be a good venue of curriculum enhancement as well as institutional development. This study aimed to trace the graduates of the FIM during the year 2013 to 2015 . Specifically, the study sought to find answers to the following research objectives:

a. To investigate the Graduate Employability (GE) trend of IM students for the past 3 years.

b. To investigate whether IM students working in their field of study.

c. To propose some of the potential business activities in IM industry.

\section{METHODOLOGY}

The descriptive method, specifically the normative survey, was used to discover facts on which professional judgment was made on the graduates based on such areas as a place of employment or self-employment after graduation from the university. The researchers were able to acquire data by analyzing 3 years of UiTM Tracer Study through e-mail and website by outright answering the questionnaires before they can borrow graduation rob and attending convocation. 
The University graduate tracer study provides the desirable information as to what is happening to university new graduates when they join the market workforce. It is equally important to find out how adequate is the education provided by the university in the overall performance of their career life, the extent by which the knowledge, communication and other skills have been developed. This tracer study also can provide valuable information for evaluating the results of education and training in the university and thereby serve as a basis for future planning activities. The graduates included in this survey are the FIM Graduates of School Year 2013 to 2015.

\section{TRENDS OF ENTREPRENEURSHIP IN INFORMATION MANAGEMENT STUDENTS}

Figure 1 below indicates a three (3) years graduate employability trend of IMS. From the findings, there was increase percentage of students employed. Although the number of students employed is only $56.6 \%$, this is due to the fact that previously the students only can find their job in less than 6 months as compared to other universities. In 2016, UiTM has already implemented an intervention to push the percentage up by doing skip convocation. This intervention gives more time to the students in finding their first job. Figure 1 reveals the reason why this percentage (56.6\%) was considerably low (UiTM target is $78 \%$ and national target is $80 \%$ ). Among the reasons were still seeking employment, the work offered is not suitable, want to rest, not interested in working, prefer not to work and lack of self-confidence to enter the market.

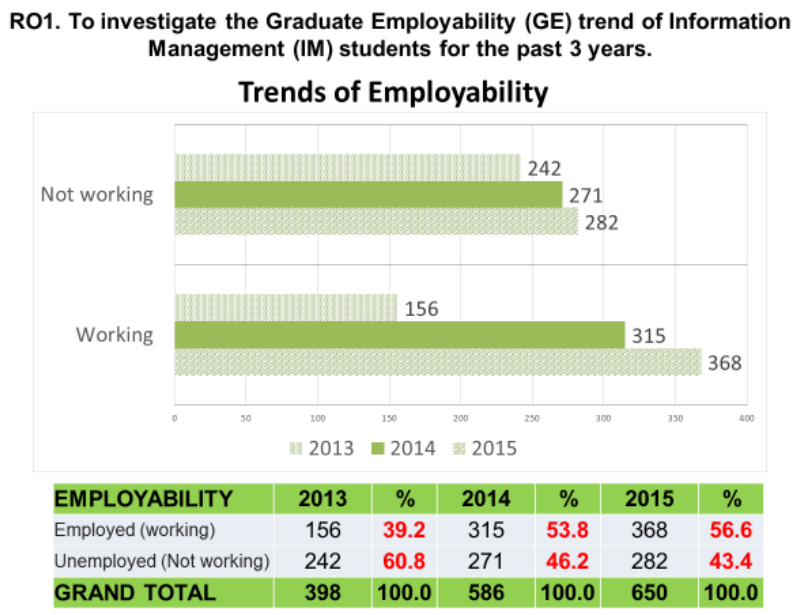

Figure 1: Trends of employability

Table 2 indicates types of business related to their study. Although the types of the business involved were multidiscipline but some of the business also can be related to internet-based information businesses such as Online business (e-business/online), Education (Tuition Centre/ Nursery/Tutors/Child Care Centre, Printing/Advertising/Graphic, Cybercafé/ Telecommunications, Developers System/Software. As stated by David \& Dube $(2013,1)$, students have been making initiatives to establish internet-based information businesses but lack 
further business and technical skills necessary to translate these initiatives into real businesses. El-Kalash \& Aniki $(2016,242)$ listed some activities that are carried out by infopreneurs which is automation of records management systems; content analysis and development; data services like database development and support and data analysis; freelance teaching; graphic designing; knowledge management consultancy; marketing of company information products; paid blogging services and project publishing consultancy.

Table 2: Types of business related to the study

\begin{tabular}{|c|c|c|c|}
\hline TYPES OF BUSINESS & 2015 & 2014 & 2013 \\
\hline Food Processing \& Manufacturing & 7 & 0 & 0 \\
\hline Tallors / Boutiques & 6 & 0 & 1 \\
\hline Online business (e-business / online) & 5 & 6 & 0 \\
\hline Restaurant / cafe & 5 & 4 & 2 \\
\hline Education (Tuition Center / Nursery / Tutors / Child Care Center & 3 & 1 & 0 \\
\hline Grocery Store / Supermarket & 2 & 1 & 1 \\
\hline Printing / Advertising / Graphic & 2 & 0 & 1 \\
\hline Building Contractor / Electrical / Plumbing / etc & 1 & 2 & 0 \\
\hline Catering and decor & 1 & 0 & 0 \\
\hline Cybercafe / Telecommunications & 1 & 0 & 1 \\
\hline Direct selling & 1 & 1 & 0 \\
\hline Etc & 1 & 0 & 0 \\
\hline Trade & 1 & 0 & 0 \\
\hline Workshop & 1 & 0 & 0 \\
\hline Purchase Gold & 0 & 1 & 0 \\
\hline Developers System / Software & 0 & 1 & 0 \\
\hline Animal / Agriculture & 0 & 1 & 0 \\
\hline Own business & 0 & 0 & 1 \\
\hline Food Processing \& Manufacturing & 0 & 0 & 1 \\
\hline Supply & 0 & 0 & 1 \\
\hline GRAND TOTAL & 37 & 18 & 9 \\
\hline
\end{tabular}

Figure 2 shows that there were 17 commercial records centre (local and international based) already operates in Malaysia since 1973. For storage facilities that also stored some records and documents, five (5) of the company has already operates since 2007 (Figure 3) and for data centres, it has operated since 1982 with six (6) companies (Figure 4). This shows that the potential for information management business is booming in Malaysia.

For research objective that is to propose some of the business activities in IM that can potentially be explored by the IM student, finding from the literature survey stated that in Malaysia, the market value of between RM30-35 millions in 2007 with a double-digit growth of about 15-30\% over the past few years (Cheng, 2008). A lot of individuals and organizations are increasingly accepting the importance of information and knowledge for their survival and are investing a great deal in information as a commodity (Abdullahi, 2015). TIME AIMS company which was one of the leading IT company in Malaysia that provide service for data storage is also targeting a $20 \%$ growth in revenue this year, more than four times the targeted growth rate of its peers in the Malaysian data centre industry (Jayaraman, 2016). 
INTERNATIONAL JOURNAL OF ACADEMIC RESEARCH IN BUSINESS AND SOCIAL SCIENCES Vol. 8, No. 12, Dec, 2018, E-ISSN: 2222-6990 ㄷ 2018 HRMARS

\section{CRC in MALAYSIA}

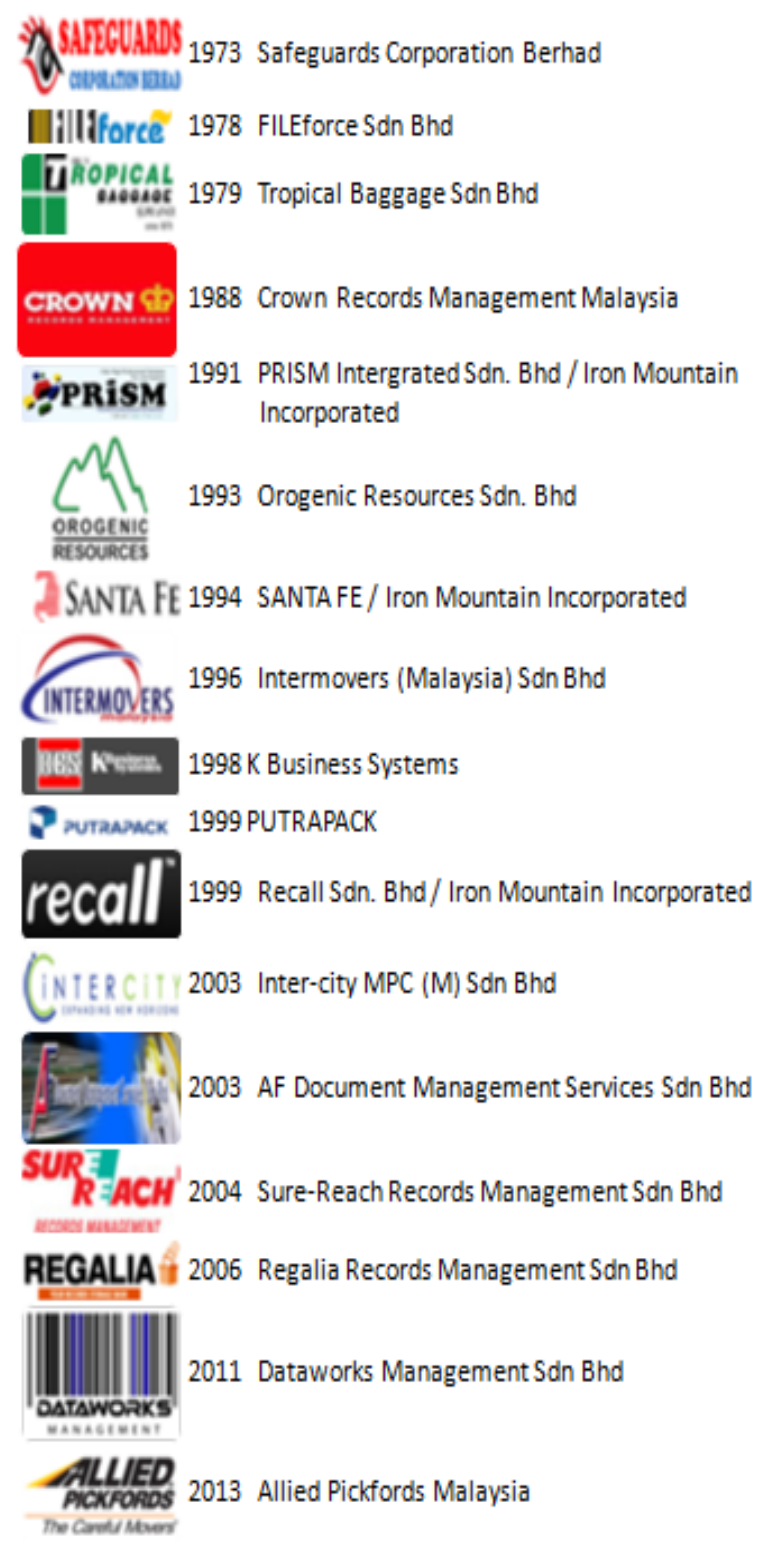

Figure 2: CRC in Malaysia

AllM Market Intelligence (2016) in their white paper report has revealed their key finding highlighting that information management (IM) is the state of the industry in 2016. Among the key finding area that have the potential to be explored are IM Drivers and Adoption, Content Lifecycle, Enterprise Content Management (ECM) Systems, Workflow and Business Process, ECM within the Enterprise, Cloud and Analytics and last but not least Opinions and Spend. This white paper report can give some ideas and open up the possibilities in exploring into the infopreneurship. 
5 Storage Facilities in MALAYSIA

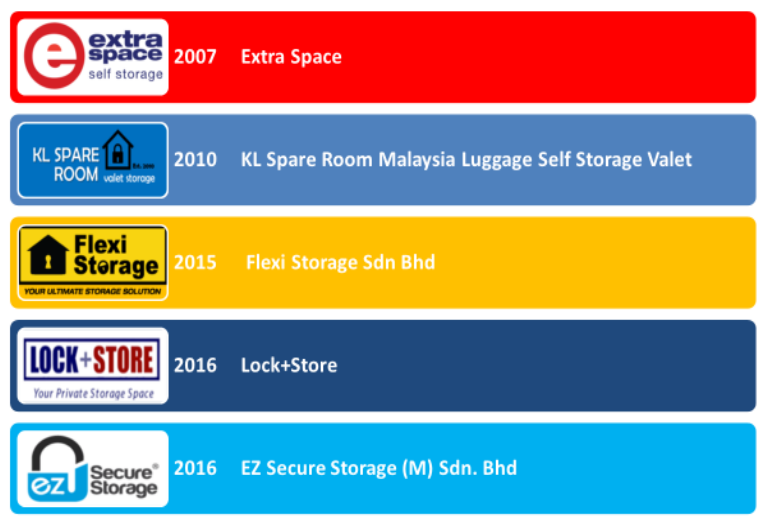

Figure 3: Storage facilities in Malaysia

$6 \mathrm{IT} / \mathrm{IM} /$ Data Center Company in MALAYSIA

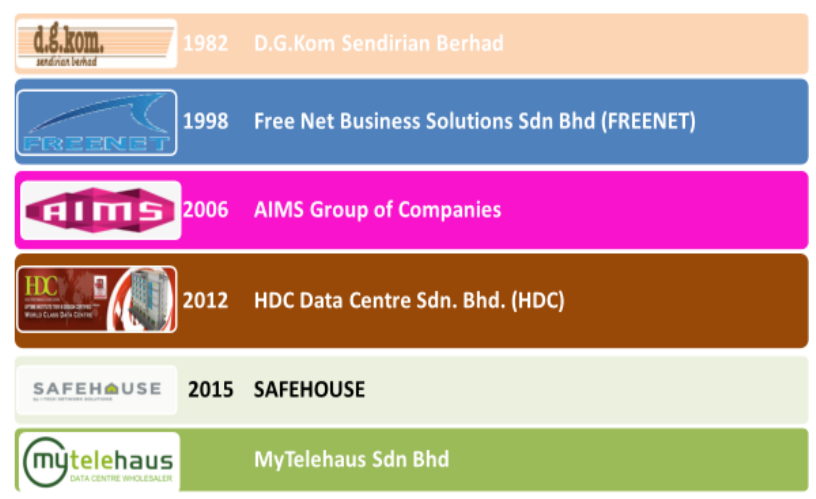

Figure 4: Data Centre in Malaysia

\section{EXPLORING INFOPRENEURSHIP FOR ECONOMIC GROWTH}

The benefits of economic growth are many: the more that businesses and nations grow and profit, the more individuals have jobs, resources and quality of life. Economic growth derived from all these technological marvels does indeed feed on itself, as consumers demand more and more. Interestingly, sustaining something may well be necessary through the integration of other factors i.e. ecological, social and economic issues but our continued emphasis on the economic growth we know today is diametrically opposed to sustainability of our planet and addressing the paradox between economic growth and sustainability requires a balancing to enable the duo to coexist. This balancing may only be possible via developing alternative energy sources and mostly by dramatically containing the growth spirals of economy, population and depletion of resources. For this reason, Malaysia's economic growth can be enhanced via a massive infopreneurial practice. Though, the impact of infopreneurs has had a disruptive impact by slicing through the traditional publishing industry by way of stepping away from agents, distribution channels, 
publishers and retailers; there is no gainsaying the fact that the 21st century is one that gives prominence to specialized and knowledge-intensive services as contributors of future growth.

In the words of Abdullahi (2015), a lot of individuals and organizations are increasingly accepting the importance of information and knowledge for their survival and are investing a great deal in information as a commodity. As such, the business of packaging and marketing information products for income generation has come to stay in the field of librarianship and allied information professions. Hence, the information professionals ought to be fully equipped with that income generating skills and strategies that will empower them to reposition themselves in the society as unemployment is currently becoming a norm especially in Malaysia. In other words, the best and alternate solution would be infopreneurship, where information professionals use their initiative i.e. creative thinking; strategic planning; focused and purposeful marketing; a willingness to be innovative and at times; take risks. However, startup capital; ICT skills; passion for the business; proper planning and management skills; adequate infrastructure like electricity provision and awareness of business opportunities in the information sector are some of the key things that would be required in order to sustain an infopreneur in addition to his/ her basic academic strength and potential in other fields. That would bring about the creative abilities to initiate, establish and run a business that will contribute to self and national development and boosts the frontier of entrepreneurship and helps in employment generation in Malaysia. Chu, Kara \& Benzing (2010), studies indicate that small enterprises are the leading force in the development for economic growth in many developing countries. As such, infopreneurship can be an instrumental factor towards economic growth, balanced regional development and job creation in Malaysia.

\section{CONCLUSION}

Ever since information plays a vital role in making this world go round, the tendency of people or organization to obtain their desired information has made information as one of the most traded commodities in the world. UiTM education and training on IM to business organizations in Malaysia would be welcomed to creates opportunity, to further leverage on the strength and potential, as businesses are aware of the need to keep reliable information in performing their routine activities. In the current economy in Malaysia, this is a good opportunity for IM entrepreneurs to market their product and services. It is timely, now for UiTM to leapfrog into a completely new and yet radical ideas of producing a pool of talent among students to start up their own companies while on campus. The survey reveals that many companies need to retain important documents, data and records. Companies need to be awakened to the fact that keeping data / information / records is essential. Experience shows that in the developed countries poor information management can lead to company closure. With the professional qualification in hand, this is an opportunity for the students in IM for exploring the potential services offered in this line of business and become infopreneur. This idea if successfully implemented will not only realize the entrepreneurial agenda of the University, but of paramount importance is to complement the agenda of the national vision of being an advanced economy growth as well as high income nation. 
INTERNATIONAL JOURNAL OF ACADEMIC RESEARCH IN BUSINESS AND SOCIAL SCIENCES

Vol. 8, No. 12, Dec, 2018, E-ISSN: 2222-6990 (C) 2018 HRMARS

\section{ACKNOWLEDGEMENT}

This article was partially funded by the Faculty of Information Management, UiTM and Fundamental Research Grant Scheme (FRGS), Ministry of Higher Education (MoHE), Malaysia. (Ref: FRGS/1/2015/SS03/UITM/02/17).

\section{REFERENCES}

Abdullahi, F. (2015). Prospects and challenges of Entrepreneurship in Librarianship in Nigeria." Paper presented at

the 2nd Conference of Certified Librarians' of Nigeria, at National Space Research Development Agency (NASRDA), Abuja, October 11-16, 2015.

AlIM Market Intelligence. Information management: state of the Industry 2016. AlIM Industry Watch. Silver Spring: MD, 2016.

Chew, J. (2010). "Infopreneurship: the next big thing". Accessed on June 20, 2016 at: http://www.ultimatedestinyuniversity.org/INFO/the next big thing.htm. National Space Research Development Agency (NASRDA), Abuja.

Christozov, Denchev, S., Toleva-Stoimenova \& K. Rasheva-Yordanova, K. (2008) "Training information brokers: A curriculum model." Informing Science and Information Technology (5), 8794.

Hung M.C., Orhan, K. \& Cynthia, B. (2010) "An empirical study of Nigerian entrepreneurs: success, motivations, problems, and stress". International Journal of Business Research (2010) Accessed on August 16, 2010 at

http://findarticles.com/p/articles/mi_6773/is_2_8/ai_n31121252/

Coulson-Thomas, C. (2011) "Shaping things to come: strategies for creating alternative enterprises." Industrial and Commercial Training, 33(5),154-156.

David, R. \& Dube, A. (2013), "Infopreneurial Behaviour among University Graduates in the Information Science Faculty of a University in Zimbabwe" Infopreneurship Journal 1 (2), 262-270. Accessed June 19, 2016. http://ir.nust.ac.zw/xmlui/handle/123456789/381

El-Kalash, Isa, K., Mohammed, S.B \& Aniki, M.Y. (2016), Exploring Infopreneurship for Economic Growth and Sustainability in a Developing Economy: The Nigeria Perspective. Journal of Educational Policy and Entrepreneurial Research (JEPER) 3(7), 240-249.

Dick, A. (2002) The philosophy, politics and economics of information. Pretoria: UNISA 
INTERNATIONAL JOURNAL OF ACADEMIC RESEARCH IN BUSINESS AND SOCIAL SCIENCES Vol. 8, No. 12, Dec, 2018, E-ISSN: 2222-6990 (C) 2018 HRMARS

Toit, A.D. (2000)“A Teaching infopreneurship: students' perspectives.” ASLIB Proceedings, 52(2) (2000): 83-90. "Faculty of Information Management," last modified Jan 1, 2017, http://fim.uitm.edu.my/en/

Ikoja-Odongo, R. \& Mostert. J. (2006) Information-seeking behavior: a conceptual framework. South African Journal of Library and Information Science, 72(3),145-158.

Premalatha, J. (2016) “TIME's AIMS Sees Expansion To More Asean Locations," The Malaysia Reserve, November 10, 2016, http://themalaysianreserve.com/new/story/time\%E2\%80\%99saims-sees-expansion-more-asean-locations

Khosrowjerdi, M. (2014) Infopreneurship from the perspective of great infopreneurs: an interview with Dan Poynter." Infopreneurship Journal, 1(2), 49-52.

Kroll, H. \& Liefner, I. (2008) Spin-off enterprises as a means of technology commercialization in a transforming economy-evidence from three universities in China," Technovation. 28(5), 298.

Lahm, R.J., Jr. \& Stowe, C.R.B. (2011) Infopreneurship: Roots, Evolution and Revolution. Entrepreneurial Executive. The Dream Catchers Group (16),107-119.

National Council for Graduate Entrepreneurship (NCGE). "New Networks launched to boost university entrepreneurship." Accessed January 2, 2017, http://ncge.wordpress.com.

Ramugondo, L. S. (2010) An Exploratory study of infopreneurship as a job option for Library and Information Science students: a literature review." Paper presented at the $11^{\text {th }}$. DIS Annual Conference, Richardsbay, University of Zululand, South Africa, September 2 - 3, 2010.

Rothaermel, F.T., Agung, S.D. \& Jiang, I. (2007) “University Entrepreneurship: a Taxonomy of the Literature, Industrial and Corporate Change", Oxford University Press 16 (4),691-791.

Bakar, S.H.A. (2017)“ 'Being an Entrepreneurial University: lessons learnt from Malaysia.' Paper presented at the University of Swansea, (n.d), 2014. Access January 1, 2017, http://www.swansea.ac.uk/media/SAHOL\%20HAMID\%20ABU\%20BAKAR.pdf.

Sultan Nazrin, S.N.S. (2017) Titah DuliYang Maha Mulia Paduka Seri Sultan Perak Darul Ridzuan." Paper presented at the Konvensyen Nasional Penyatuan Bangsa 2016, Universiti Teknologi MARA (UiTM), Shah Alam, Malaysia, November 8-10, 2016, Access January 1, 2017, http://www.astroawani.com/berita-malaysia/uitm-bukan-sebarang-universiti-sultan-nazrinmuizzuddin-shah-121895

UiTM Facts and Figures 92016).Last modified Disember 31, 2016, http://www.uitm.edu.my/en/ 
INTERNATIONAL JOURNAL OF ACADEMIC RESEARCH IN BUSINESS AND SOCIAL SCIENCES

Vol. 8, No. 12, Dec, 2018, E-ISSN: 2222-6990 @ 2018 HRMARS

Centre for Strategic Planning and Information (CSPI)." UiTM Puncak Alam, Oktober, 23 24 (2014). 